\title{
The Polarity Protein Pals1 Regulates Radial Sorting of Axons
}

\author{
Daniel R. Zollinger, ${ }^{1}$ Kae-Jiun Chang, ${ }^{1}$ Kelli Baalman, ${ }^{1}$ Seonhee Kim, ${ }^{2}$ and Matthew N. Rasband ${ }^{1}$ \\ ${ }^{1}$ Department of Neuroscience, Baylor College of Medicine, Houston, Texas 77030, and ${ }^{2}$ Department of Anatomy and Cell Biology, Temple University School \\ of Medicine, Philadelphia, Pennsylvania 19140
}

Myelin is essential for rapid and efficient action potential propagation in vertebrates. However, the molecular mechanisms regulating myelination remain incompletely characterized. For example, even before myelination begins in the PNS, Schwann cells must radially sort axons to form 1:1 associations. Schwann cells then ensheathe and wrap axons, and establish polarized, subcellular domains, including apical and basolateral domains, paranodes, and Schmidt-Lanterman incisures. Intriguingly, polarity proteins, such as Pals1/Mpp5, are highly enriched in some of these domains, suggesting that they may regulate the polarity of Schwann cells and myelination. To test this, we generated mice with Schwann cells and oligodendrocytes that lack Pals1. During early development of the PNS, Pals1-deficient mice had impaired radial sorting of axons, delayed myelination, and reduced nerve conduction velocities. Although myelination and conduction velocities eventually recovered, polyaxonal myelination remained a prominent feature of adult Pals1-deficient nerves. Despite the enrichment of Pals1 at paranodes and incisures of control mice, nodes of Ranvier and paranodes were unaffected in Pals1deficient mice, although we measured a significant increase in the number of incisures. As in other polarized cells, we found that Pals 1 interacts with Par3 and loss of Pals1 reduced levels of Par3 in Schwann cells. In the CNS, loss of Pals1 affected neither myelination nor the establishment of polarized membrane domains. These results demonstrate that Schwann cells and oligodendrocytes use distinct mechanisms to control their polarity, and that radial sorting in the PNS is a key polarization event that requires Pals1.

Key words: axon; myelin; polarity; Schwann cell

Significance Statement

This paper reveals the role of the canonical polarity protein Pals1 in radial sorting of axons by Schwann cells. Radial sorting is essential for efficient and proper myelination and is disrupted in some types of congenital muscular dystrophy.

\section{Introduction}

During development of the PNS, myelinating Schwann cells sort and wrap axons in a myelin sheath to enable fast, efficient, and reliable action potential propagation. Although some of the factors that control myelination have been described (Michailov et al., 2004; Taveggia et al., 2005), the mechanisms regulating many other Schwann cell functions remain poorly understood. For example, how Schwann cells sort axons, initiate myelination, exe-

Received April 24, 2015; revised May 22, 2015; accepted June 12, 2015.

Author contributions: D.R.Z. and M.N.R. designed research; D.R.Z., K.-J.C., and K.B. performed research; S.K. contributed unpublished reagents/analytic tools; D.R.Z., K.-J.C., and M.N.R. analyzed data; D.R.Z. and M.N.R. wrote the paper.

This work was supported by National Institutes of Health Grants NS069688 and NS044916 to M.N.R. Electron microscopy was conducted at the Integrated Microscopy Core at Baylor College of Medicine by D.R.Z. (supported by Grants U54 HD-07495-39, P30 DX56338-05A2, P39 CA125123-04, and S10RR027783-01A1). We thank Dr. KlausArmin Nave (Max Planck Institute of Experimental Medicine) who provided the CNP-Cre mice; and Drs. M. Laura Feltri and Lawrence Wrabetz (Hunter James Kelly Research Institute, University at Buffalo, State University of New York) and Steven S. Scherer (University of Pennsylvania) for helpful discussions.

The authors declare no competing financial interests.

Correspondence should be addressed to Dr. Matthew N. Rasband, Department of Neuroscience, Baylor College of Medicine, One Baylor Plaza, Houston, TX 77030. E-mail: rasband@bcm.edu.

DOI:10.1523/JNEUROSCI.1593-15.2015

Copyright $\odot 2015$ the authors $\quad 0270-6474 / 15 / 3510474-11 \$ 15.00 / 0$ cute the dramatic cytoskeletal rearrangements necessary for axon wrapping and myelin extension, and form distinct subcellular membrane domains remains poorly understood.

Many cell types with remarkable morphologies are polarized, with subcellular domains that are structurally, molecularly, and functionally unique. Recently, insights into the mechanisms of myelination have come from viewing it as yet another example of cellular polarization (Salzer, 2003; Masaki, 2012; Simons et al., 2012). In epithelial cells, a well-characterized model of polarity, three main complexes regulate polarization and junction formation: (1) the Par complex, consisting of Par3, Par6, and atypical protein kinase $\mathrm{C}(\mathrm{aPKC})$, provides the signaling complex that regulates formation of the apical domain. (2) The Scribble complex, consisting of Scribble, discs largel (DLG1), and lethal giant larva (LGL), signals the formation of the basolateral domain. The Par and Scribble complexes locally inhibit each other, giving rise to cell polarity. (3) The Crumbs complex, consisting of Crumbs, protein associated with Lin-7 (Pals1/Mpp5), and Pals1 associated tight junction protein (PatJ), acts to anchor the Par complex to the membrane and to aid in junction formation (Straight et al., 2004; Assémat et al., 2008; Mellman and Nelson, 2008; Kim et al., 2010; Park et al., 2011). Although many canonical polarity pro- 
teins localize to an apical-like domain in Schwann cells (including Schmidt-Lanterman incisures (SLIs), paranodal loops, and adaxonal junctions) (Poliak et al., 2002; Ozçelik et al., 2010) and loss of Par3 inhibits myelination in vitro and in vivo (Chan et al., 2006; Tep et al., 2012), interactions among polarity proteins and the signaling pathways they regulate can vary depending on cell context and even species (McCaffrey and Macara, 2009). Thus, mechanisms of polarization must be identified and confirmed for each unique cell type, including myelinating glia.

Previously, efforts to define the role of polarity in myelination included silencing of Pals1 using lentiviral vectors to deliver Pals1 shRNA into postnatal sciatic nerve. These experiments suggested that Pals1 plays essential roles in regulating myelin sheath thickness and length (Ozçelik et al., 2010). However, postnatal viral transduction of Schwann cells and the use of shRNA limits the temporal precision and efficiency of Pals1 deletion. To circumvent these limitations and to determine the role of polarity and of Pals1 throughout PNS and CNS myelin development, we genetically disrupted Pals1 in myelinating glia. We found that Pals1dependent polarization events play important roles in radial sorting of axons and myelination by Schwann cells, but that Pals 1 is dispensable for CNS myelination by oligodendrocytes.

\section{Materials and Methods}

Animals. Mpp $5^{f l f l}$ mice, hereafter referred to as $P a l s 1^{f l / f l}$, were previously described (Kim et al., 2010). The CNP-cre mice were a generous gift from Dr. Klaus Nave (Lappe-Siefke et al., 2003). All experiments were performed in compliance with the National Institutes of Health Guide for the Care and Use of Laboratory Animals and were approved by the Baylor College of Medicine Institutional Animal Care and Use Committee. A minimum of three mice of either sex were used per experiment.

Antibodies. The primary antibodies used were as follows: chicken anti$\beta$ IV spectrin SD (Chang et al., 2010), rabbit anti- $\beta$ IV spectrin SD (Yang et al., 2004), rabbit anti-Caspr (Schafer et al., 2004), rabbit antigliomedin (provided by Dr. Elior Peles) (Eshed et al., 2005), rabbit antiNav1.6 (Schafer et al., 2006), rabbit anti-Kv1.2 (Zhang et al., 2013), chicken anti-pan neurofascin (AF3235, R\&D Systems), sheep anti-Pals1 (AF7979, R\&D Systems), mouse anti-actin (MAB1501, Millipore), mouse anti-Caspr (K65/35, NeuroMab), rabbit anti-ZO-1 (40-2200, Invitrogen), rabbit anti-Par3 (07-330, Millipore), and rabbit anti-P75NTR (G323A, Promega). Secondary antibodies were purchased from Invitrogen or Jackson ImmunoResearch Laboratories.

Immunoblotting and immunoprecipitation. Sciatic nerves from P21 mice were homogenized with sonication in homogenization buffer $(320$ $\mathrm{mm}$ sucrose, $5 \mathrm{~mm}$ sodium phosphate, $\mathrm{pH} 7.2,0.2 \mathrm{~mm} \mathrm{NaF}, 0.2 \mathrm{~mm}$ $\mathrm{Na}_{3} \mathrm{VO}_{4}, 1 \times$ PhosSTOP, $2 \mu \mathrm{g} / \mathrm{ml}$ aprotinin, $1 \mu \mathrm{g} / \mathrm{ml}$ leupeptin, $2 \mu \mathrm{g} / \mathrm{ml}$ antipain, $10 \mu \mathrm{g} / \mathrm{ml}$ benzamidine, and $0.5 \mathrm{~mm}$ PMSF). Homogenates were centrifuged at $700 \times g$ for $10 \mathrm{~min}$ at $4^{\circ} \mathrm{C} ; 20 \mu \mathrm{g}$ of supernatant was boiled in reducing sample buffer and run on a $10 \%$ SDS-PAGE gel. The gel was then transferred to nitrocellulose membrane. Membranes were blocked with $20 \mathrm{~mm}$ Tris, pH 8.0, containing 4\% (w/v) milk and $0.05 \%(\mathrm{v} / \mathrm{v})$ Tween 20. Primary antibodies were incubated overnight at $4^{\circ} \mathrm{C}$, and secondary antibodies were incubated for $1 \mathrm{~h}$ at room temperature. For immunoprecipitation, rabbit anti-Par3 and sheep anti-Pals1 were conjugated to protein-A agarose (Thermo Scientific) and protein-G Sepharose beads (GE Healthcare), respectively. Sciatic nerve homogenates were diluted to a final protein concentration of $1 \mathrm{mg} / \mathrm{ml}$ with lysis buffer $(0.5 \%$ (final v/v) Triton X-100, 20 mm Tris-HCl, pH 8.0, 10 mм EDTA, 150 mм $\mathrm{NaCl}, 10 \mathrm{~mm} \mathrm{NaN}_{3}, 1 \times$ PhosSTOP, $2 \mu \mathrm{g} / \mathrm{ml}$ aprotinin, $1 \mu \mathrm{g} / \mathrm{ml}$ leupeptin, $2 \mu \mathrm{g} / \mathrm{ml}$ antipain, $10 \mu \mathrm{g} / \mathrm{ml}$ benzamidine, and $0.5 \mathrm{~mm}$ PMSF) and rotated for $1 \mathrm{~h}$ at $4^{\circ} \mathrm{C}$. Lysates were spun at $13,000 \times g$ at $4^{\circ} \mathrm{C}$ for $30 \mathrm{~min}$. Supernatants were loaded on the beads and rotated overnight at $4^{\circ} \mathrm{C}$. Beads were boiled in reducing sample buffer after 4 washes with lysis buffer to elute bound proteins.

Immunostaining. Immunostaining was performed as described previously (Ogawa et al., 2006). In brief, tissues were dissected, fixed in $4 \%$ PFA, cryoprotected in $20 \%$ sucrose, cryosectioned, and mounted on cov- erslips. In some cases, nerves were fixed as above and individual axons were gently teased apart on coverslips with fine-tipped forceps. Tissues were blocked in $0.1 \mathrm{M}$ sodium phosphate, $\mathrm{pH}$ 7.4, containing either $10 \%$ goat serum (Invitrogen) or 5\% donkey serum (Equitech-Bio) and $0.3 \%$ Triton X-100. Primary antibodies were added overnight at $4^{\circ} \mathrm{C}$. Tissues were washed, and secondary antibodies were added for $\geq 1 \mathrm{~h}$. The coverslips were then washed, air dried, and mounted. All images were acquired using a Zeiss Imager Z1 fluorescence microscope fitted with a Zeiss AxioCam Mrm CCD camera (Carl Zeiss). Microscope objectives used in this study included $20 \times(0.8 \mathrm{NA})$ air, $40 \times(0.75 \mathrm{NA})$ air, and $63 \times$ (1.4 NA) oil objectives. Image analysis was performed using Zen software from Carl Zeiss or ImageJ (National Institutes of Health), and figures were cropped and assembled using Adobe Photoshop and Adobe Illustrator. For measurement of internodal lengths, multiple fields were merged in Adobe Photoshop.

Explant cultures. Coverslips were washed with $1 \mathrm{~N} \mathrm{NaOH}, 1 \mathrm{~N} \mathrm{HCl}$, then $1 \mathrm{~N} \mathrm{H}_{2} \mathrm{SO}_{4}$ for $1 \mathrm{~h}$ each followed by three washes with milliQ water. Coverslips were autoclaved, cooled, dried, and coated with Matrigel (Corning) for $1 \mathrm{~h}$. Coverslips were washed and stored in Minimal Essential Media containing $4 \mathrm{mg} / \mathrm{ml}$ glucose, 10\% FBS, $1 \times$ Glutamax, 50 $\mathrm{ng} / \mathrm{ml} \mathrm{NGF}$, and $1 \times$ penicillin/streptomycin. Postnatal day 0 pups were anesthetized on ice and decapitated. DRGs were removed and placed on coverslips. Cultures were then incubated at $37^{\circ} \mathrm{C}, 5 \% \mathrm{CO}_{2}$ for $24 \mathrm{~h}$. Media was replaced with Neurobasal media containing $1 \times$ B27 supplement, $4 \mathrm{mg} / \mathrm{ml}$ glucose, $2 \mathrm{~mm}$ L-glutamine, $50 \mathrm{ng} / \mathrm{ml} \mathrm{NGF}$, and $1 \times$ penicillin/streptomycin. Neurobasal media was changed $2 \mathrm{~d}$ later. At $1-2 \mathrm{~d}$ later, cells were fixed in 4\% PFA for $20 \mathrm{~min}$ on ice. All reagents were purchased from Invitrogen or Thermo Scientific unless otherwise indicated.

Transmission electron microscopy. Electron microscopy was performed as previously described (Chang et al., 2010). In brief, mice were anesthetized with ketamine $(80 \mathrm{mg} / \mathrm{kg})$ and xylazine $(16 \mathrm{mg} / \mathrm{kg})$ by intraperitoneal injection. Mice were then perfused with $2 \%$ PFA $/ 2.5 \%$ glutaraldehyde in cacodylate, $\mathrm{pH} 7.4$, then immersion fixed overnight at $4^{\circ} \mathrm{C}$. Tissues were postfixed with $4 \%$ osmium tetroxide, dehydrated, and then embedded in Spurr's resin. Thick sections were cut at $1 \mu \mathrm{m}$ on an RMC Ultramicrotome $6000 \times \mathrm{L}$ and stained with toluidine blue. Thin sections were cut at $<65 \mathrm{~nm}$. Sections were stained with lead citrate followed by uranyl acetate. Images were acquired on a Hitatchi H7500 or JOEL 1230 with $80 \mathrm{kV}$ accelerating voltage and a Gatan US1000 highresolution 4MP digital camera. Images were analyzed using ImageJ. All reagents were purchased from Electron Microscopy Sciences.

Compound action potential (CAP) recordings. CAP recordings were performed as described previously (Zhang et al., 2013). In brief, nerves were dissected and placed in oxygenated Locke's solution containing 1 $\mathrm{mg} / \mathrm{ml}$ glucose. Nerves were drawn into suction electrodes, and increasing current was applied (Digitimer, model DS3) until a supramaximal threshold was reached. CAPs were amplified with a Warner DR-311 differential amplifier and converted using a Digidata 1440A and Clampex 10.2 software (Molecular Devices). Data were analyzed using Clampfit (Molecular Devices). CAP latency was the difference between stimulus onset and the time of maximal peak. Nerve length was measured using 20 $\mathrm{mm} \times 20 \mathrm{~mm}$ microscope slide grids (Electron Microscopy Sciences). Conduction velocities were calculated by dividing nerve length by CAP latency.

Behavioral analysis. Mice were acclimated on the rotating rod (Ugo Basile) for $5 \mathrm{~min}$ at $4 \mathrm{rpm}$ then allowed to rest for $1 \mathrm{~h}$. Mice were then tested for latency to fall on the accelerating rod $(4-40 \mathrm{rpm})$ for $5 \mathrm{~min}$ over three different trials with a minimum of 30 min breaks between trials. Latencies were averaged across trials.

$q R T-P C R$. qRT-PCR was performed as previously described (Chang et al., 2014). The primers used are as follows (from $5^{\prime}$ to $3^{\prime}$ ): Pals1 (Mpp5) ex4-6 (forward: ACAGTACACATGAGCAAGG; reverse: GCTCTAGCTGCATT TCCTG), Pals1 (Mpp5) ex1-2 (forward: GAGGAATCGGGAGTTTCTG; reverse: CCTCTCCCAATATTCAGGTTAG), Pals2 (Mpp6) (forward: GTGTGGATGAAAATGTGGC; reverse: CGAGAATACGGATGGCATC), Pals3 (Cask) (forward: TGCGAAGGAACTAAAGCG; reverse: CGAAC TCTGGTCACATTCTC), and Polr2a (forward: CATCAAGAGAGTGCAGTTCG; reverse: CCATTAGTCCCCCAAGTTTG). Polr2a was used as 

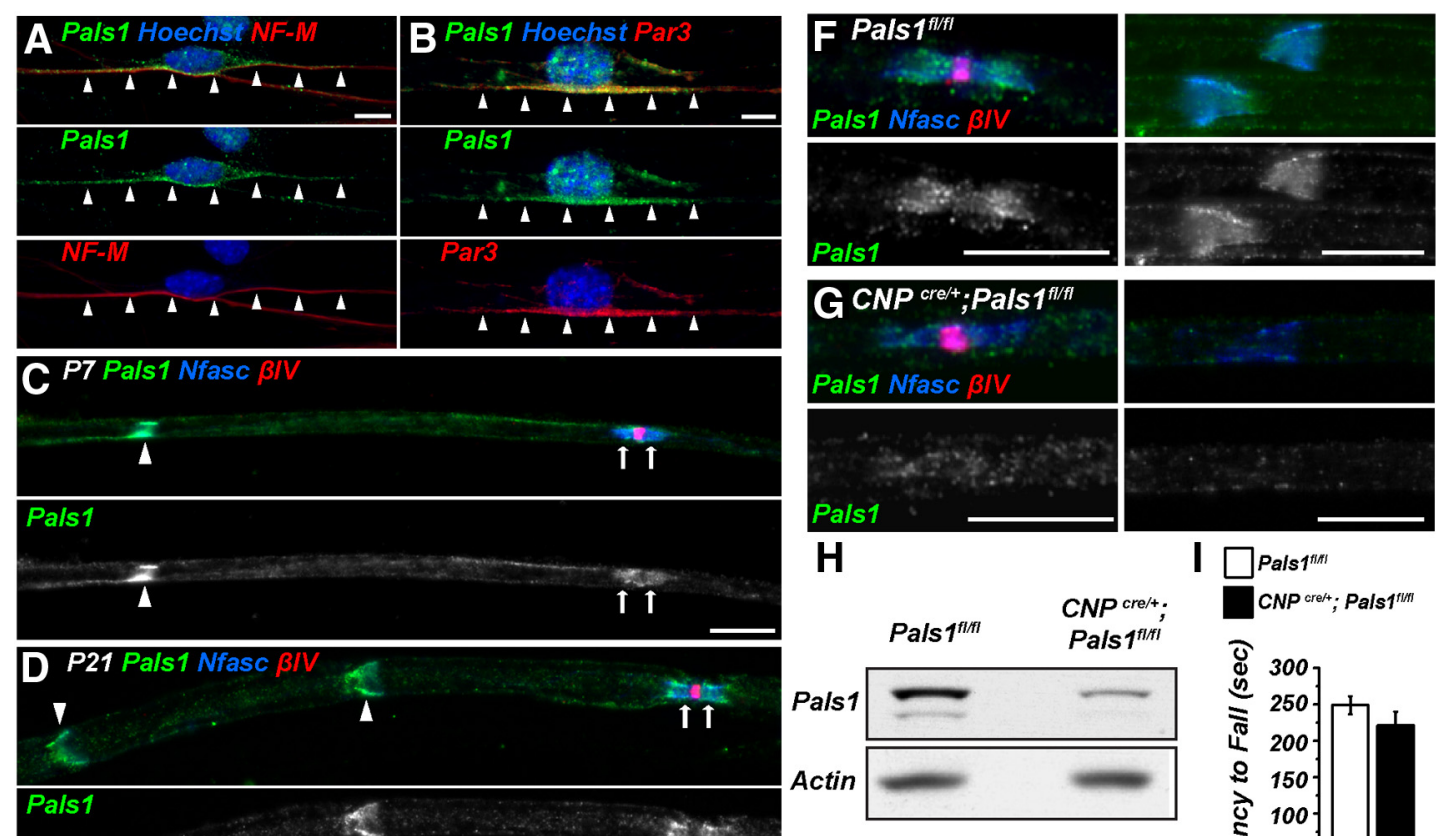

I $\square$ Palstim
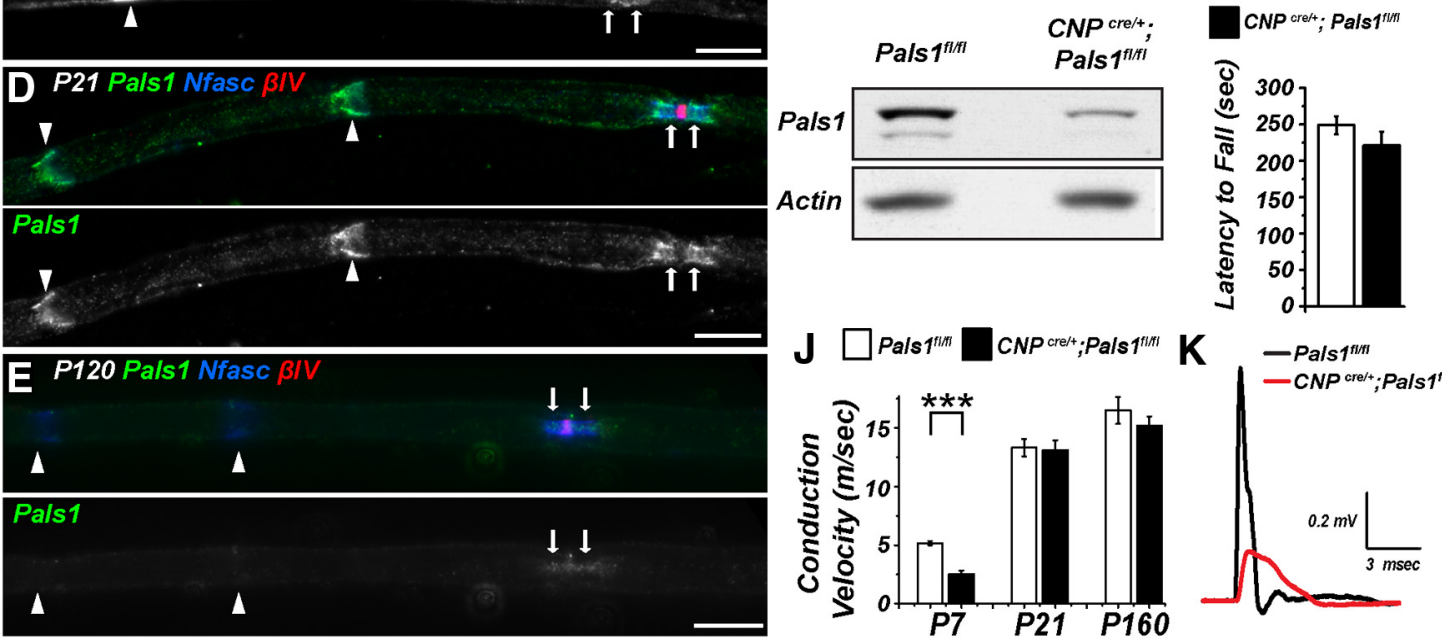

Figure 1. Pals1 is found at the axon-Schwann cell interface, paranodes, and SLI throughout development. $A$, Immunostaining of DRG explant cultures at 5 DIV using antibodies against Pals1 (green), neurofilament-M (NF-M, red), and Hoechst to label Schwann cell nuclei (blue). Arrowheads indicate the asymmetric position of the axon-Schwann cell interface. $\boldsymbol{B}$, Immunostaining of DRG explant cultures at 5 DIV for Pals1 (green), Par3 (red), and nuclei are labeled using Hoechst (blue). Arrowheads indicate the asymmetric position of the axon/Schwann cell interface. $\boldsymbol{C}-\boldsymbol{E}$, Immunostaining of teased sciatic nerves from control Pals $7^{f / / f t}$ mice. Myelinated axons were immunostained at P7 (C), P21 (D), and P120 (E) with antibodies against Pals 1 (green), $\beta \mathrm{IV} \mathrm{spectrin} \mathrm{(} \beta \mathrm{IV}$, red), and pan-neurofascin (Nfasc, blue). Paranodes and SLIs are indicated by arrows and arrowheads, respectively. $\boldsymbol{F}, \boldsymbol{G}$, Immunostaining of teased sciatic nerves from control $(\boldsymbol{F})$ and $\mathrm{KKO}(\boldsymbol{G})$ mice at P21 with antibodies against Pals 1 (green), $\beta$ IV spectrin (red), and pan-neurofascin (blue). $\boldsymbol{H}$, Immunoblots of P21 sciatic nerves from control and cK0 mice using antibodies against Pals1 and actin as a loading control. $I$, Rotarod analysis performed on control and CKO mice at P30 (mean \pm SEM, Student's $t$ test, $p=0.23, n=7$ mice). J, Average conduction velocities calculated from CAPs in P7, P21, and P160 sciatic nerves (mean \pm SEM, one-way ANOVA followed by Bonferroni correction). ${ }^{* * *} p=5.5 \times 10^{-8} . n \geq 10$ nerves. $K$, Representative CAPs from P7 sciatic nerves of equal length show reduced conduction velocity and attenuation of the CAP in cKO mice. Scale bars, $10 \mu \mathrm{m}$.

the internal control (Radonić et al., 2004). One-sample two-tailed $t$ tests were used for statistical comparison of mRNA levels in WT and cKO tissues.

Statistical analysis. Statistical analyses were performed using Student's $t$ test or one-way ANOVA followed by Bonferroni correction using OriginsPro 9.1 software. Graphs were generated in OriginPro, and figures were assembled in Abode Illustrator.

\section{Results}

Pals1 is highly polarized in Schwann cells

During early development, premyelinating Schwann cells associate with axons. The polarity protein Par3 and cytoskeletal scaffolding proteins $\alpha \mathrm{II}$ and $\beta \mathrm{II}$ spectrin establish an asymmetric, or polarized, distribution at the interface of Schwann cell-axon contact (Chan et al., 2006; Susuki et al., 2011). To determine whether Pals1 also occupies a polarized distribution in immature Schwann cells, we immunostained DRG explant cultures using antibodies against Pals1. We found that Pals1 is asymmetrically localized to the initial contact site between the premyelinating Schwann cell and the axon (arrowheads) and that it colocalizes with Par3 (Fig. 1A,B). To determine whether Pals1 is also found in polarized domains of myelinating Schwann cells, we examined
Pals1 localization in sciatic nerve at postnatal day 7 (P7), P21, and P120. Consistent with previous reports of polarity protein distribution in PNS myelin (Poliak et al., 2002; Ozçelik et al., 2010), we found that Pals1 is enriched at paranodes (arrows) and SLIs (arrowheads) at P7 and P21 (Fig. 1C,D). However, Pals1 immunoreactivity decreased after completion of myelination such that, in the adult sciatic nerve, Pals1 was no longer detected at paranodes or SLIs (Fig. 1E). Thus, Pals1 is highly polarized in premyelinating and actively myelinating Schwann cells, suggesting that it may play important roles during early development.

Loss of Pals1 causes radial sorting defects

To determine the function of Pals1 in myelination, we generated mice lacking Pals1 protein in Schwann cells and oligodendrocytes. To this end, we crossed mice with a floxed allele of Mpp5, the gene encoding Pals1 (referred to as Pals $1^{f l f l}$ ) (Kim et al., 2010), with mice expressing Cre recombinase under the control of the 2', 3'-cyclic nucleotide phosphodiesterase (CNP) promoter $\left(\mathrm{CNP}^{\mathrm{cre} /+}\right)$ (Lappe-Siefke et al., 2003); hereafter the conditional knock-out mice lacking Pals1 in myelinating glia will be 
referred to as $\mathrm{CNP}^{\mathrm{cre} /+} ; \mathrm{Pals}^{\mathrm{fl} / \mathrm{fl}}$ or $\mathrm{cKO}$ mice. Immunostaining and Western blotting of sciatic nerves confirmed the loss of Pals 1 from cKO mice (Fig. $1 F-H$ ). Specifically, cKO mice lacked Pals1 immunoreactivity in paranodes and SLIs (Fig. $1 G$ ). To determine whether $\mathrm{CKO}$ mice have gross motor dysfunction, we performed rotarod analysis on 1-month-old mice. cKO mice performed as well as littermate controls (Fig. 1I), suggesting little or no impairment in nervous system function at this age. Nevertheless, because neonatal mice cannot be tested for motor function on the rotarod, we also measured the CAP and calculated CAP conduction velocities in sciatic nerves of $\mathrm{cKO}$ and control mice at P7, $\mathrm{P} 21$, and P160. We measured a significantly attenuated CAP and slower conduction velocity in $\mathrm{P} 7 \mathrm{cKO}$ sciatic nerves (Fig. $1 \mathrm{~J}, \mathrm{~K}$ ). However, the CAP conduction velocities were indistinguishable by $\mathrm{P} 21$ (Fig. $1 J$ ).

What explains the reduced conduction velocity in the very young cKO mice? Although many things can cause a reduction in CAP amplitude and conduction velocity, the temporary nature of the reduction suggests a simple delay in myelination due to either delay in the number of axons myelinated and/or the rate at which a given axon is myelinated. To test these possibilities, we stained cross sections of resin-embedded sciatic nerves at different developmental time points with toluidine blue to visualize myelinated axons. Consistent with the notion that loss of Pals1 results in a delay in myelination, we found significantly fewer myelinated axons per field of view at P4, P7, and P21, but adult animals (e.g., P160) showed comparable myelination (Fig. $2 A, B$ ). If wrapping is delayed or impaired by loss of Pals1, myelin sheath thickness should be reduced. To test this possibility, we performed transmission electron microscopy of developing sciatic nerves (Fig. $3 A$ ). We then measured myelin thickness relative to axon caliber as G-ratios and found no significant differences in myelin thickness at any time point during development (Fig. 3B). Thus, Pals 1 regulates events preceding myelination but is not necessary for the process of myelination itself.

In addition to the delay in myelination, we also observed large regions of developing nerve with bundles of axons devoid of myelin (Fig. 2A, asterisks). During early development, promyelinating Schwann cells surround and interact with bundles of axons; the largest of these axons are then selected from this bundle for myelination through a process termed radial sorting. Axons that are not myelinated (predominantly small-diameter axons) remain associated with nonmyelinating Schwann cells in Remak bundles (Salzer, 2012; Feltri et al., 2015). Although these nonmyelinating Schwann cells do not wrap small-diameter axons with myelin, they still wrap axons with a single cytoplasm-filled process (Fig. 4A; P21 and P160). To determine whether Pals1 regulates radial sorting, we used TEM to examine the bundles of unmyelinated axons in developing peripheral nerves of control and $\mathrm{cKO}$ mice (Fig. $4 A, B$ ). In cKO mice, we found the number of axons per bundle was significantly greater than littermate controls up to P21, but this difference resolved in adult animals (Fig. $4 A-C)$. Furthermore, cKO bundles frequently contained unsorted large diameter axons ( $>1 \mu \mathrm{m}$ diameter; Fig. $4 B$, asterisks). We also noted a clear deficit in the ability of nonmyelinating Schwann cells to segregate and ensheathe axons compared with control mice (Fig. 4A, B, P21).

In adult cKO mice, approximately two-thirds of Remak bundles appeared normal with appropriate ensheathement of axons by nonmyelinating Schwann cells (Fig. 4B, P160). However, the remaining approximately one-third of bundles lacked Schwann cell processes surrounding each axon (Fig. 4D). Remarkably, some axon bundles were even myelinated (Fig. $4 E$ ). Indeed, these myelinated
A
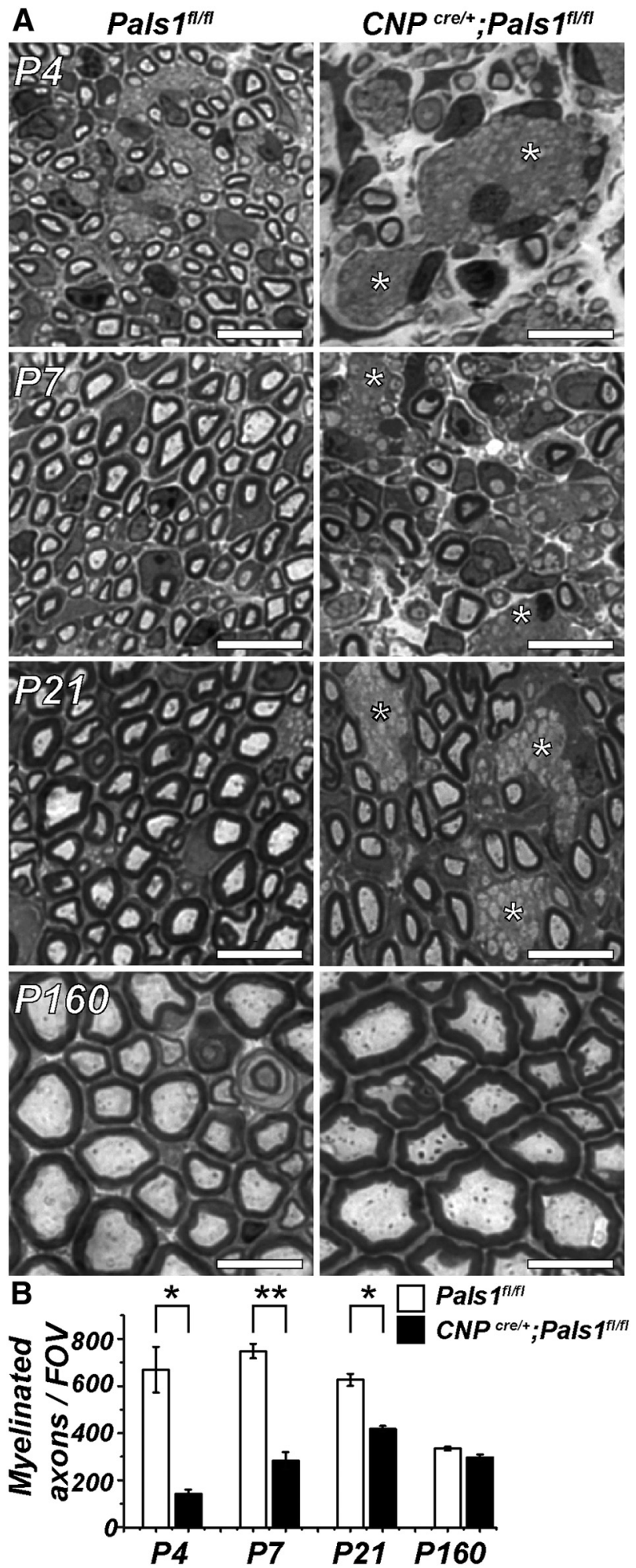

Figure 2. PNS myelination is delayed. $A$, Cross sections of sciatic nerves were stained with toluidine blue. Asterisks indicate large areas devoid of myelinated axons. $B$, Quantification of myelinated axons per field of view (mean \pm SEM, one-way ANOVA followed by Bonferroni correction). ${ }^{*} p=$ 0.014. ${ }^{* *} p=0.007 . n \geq 3$ mice. Scale bars, $10 \mu \mathrm{m}$.

bundles, termed polyaxonal myelination, were a hallmark of the cKO nerves, and we found examples in every cKO older than P21, but never in control animals. Conditional heterozygotes had an intermediate phenotype with some bundles of unsorted axons and occasional instances of polyaxonal myelination at P21 (data not 
shown), which is consistent with previous studies showing the gene-dosage dependence of Pals1 function (Kim et al., 2010). Interestingly, polyaxonal myelination has also been reported in other mouse models with disrupted radial sorting (Saito et al., 2003). Together, these results suggest that Pals1 regulates proper and efficient radial sorting of axons and development of Remak bundles.

\section{Loss of Pals1 increases SLI frequency but does not affect paranodes}

After myelination has begun, Pals 1 is highly enriched at developing paranodes and SLIs (Fig. 1), suggesting that it may have other roles in addition to regulating radial sorting. Pals1-enriched structures include both axoglial and autotypic junctions. Because Pals1 facilitates junction formation in mammalian epithelial cells, we determined whether loss of Pals1 disrupts paranodes or SLIs by immunostaining sciatic nerve with anti-neurofascin (Nfasc) antibodies that robustly label these structures (Fig. $5 A, B$, arrows and arrowheads, respectively). We found that Pals1-deficient mice had a significant increase in the number of SLIs, and this difference persisted in adults (Fig. 5B,C). Consistent with a delay in myelination, internodal length was reduced at $\mathrm{P} 21$ but recovered in adults (Fig. 5D). We observed no change in the clustering of paranodal Nfasc (Fig. $5 A, B$, arrows). Nevertheless, to more carefully determine whether loss of Pals1 affects development of the axoglial or autotypic junctions found at paranodes, we immunostained sciatic nerves using antibodies against Caspr, an essential component of the paranodal junction (Bhat et al., 2001), and ZO-1, a component of autotypic junctions (Poliak et al., 2002). Immunostaining at P4, P21, and P120 showed no defects in either paranodal axoglial or autotypic junctions (Fig. 5E,F). Furthermore, TEM analysis of paranodes and SLIs showed no disruption in cKO mice (Fig. $5 G)$. Immunostaining juxtaparanodal Kv1.2 channels showed that these channels were excluded from paranodal regions, indicating that the paranodal barrier is intact in cKO mice (Fig. $5 H$ ). Thus, loss of Pals 1 affects the number of SLIs in the myelin sheath, but not paranode function or assembly. Last, we determined whether loss of Pals1 affects the localization of the canonical polarity protein, Par3. Intriguingly, immunostaining of teased sciatic nerve showed that Par3 localizes to both paranodes and SLI in control and cKO mice (Fig. 5I).

While examining node of Ranvier organization by immunostaining with antibodies against $\beta I V$ spectrin (Fig. $5 E, F$ ), a key nodal cytoskeletal protein, we noticed frequent instances of $\beta$ IV spectrin clusters that were elongated and had abnormal morphologies. Furthermore, these clusters were found only in regions that were labeled with anti-p75 neurotrophin receptor (p75-NTR) antibodies, a marker of the nonmyelinating Schwann cells that ensheathe axon bundles (Fig. 6A) (Cosgaya
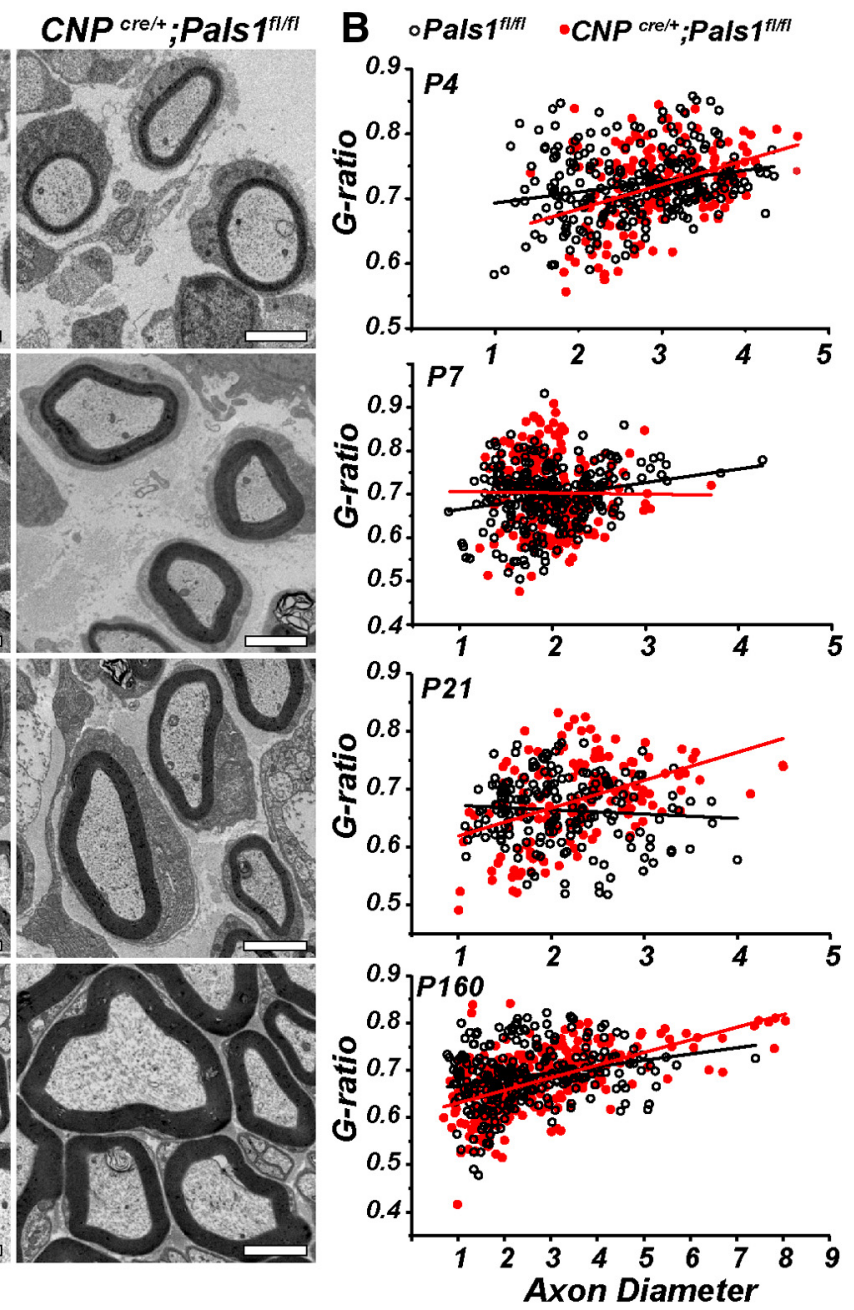

Figure 3. PNS myelin thickness is unaffected in Pals1 CK0. $\boldsymbol{A}$, Electron microscopy of myelinated axons in the sciatic nerve. $\boldsymbol{B}$, Scatter plots depicting G-ratios of control (black circles) and cKO mice (red dots). No significant differences in mean g-ratio were observed (one-way ANOVA followed by Bonferroni correction, $n=3$ mice). Scale bars, $2 \mu \mathrm{m}$.

et al., 2002). The aberrant clusters were observed at all ages in cKO mice but were never observed in control mice (Fig. 6A). Remarkably, other nodal proteins, including gliomedin, Nav 1.6, Nfasc, and ankG (Fig. 6B; ankG not shown), colocalized with $\beta I V$ spectrin in these aberrant node-like clusters. Paranodal proteins frequently flanked the clusters on one edge, forming a heminode (Fig. 6B, arrows). These observations suggest that ectopic node-like clusters may form on axons within perturbed Remak structures.

\section{Pals1 binds to Par3 in Schwann cells}

Because Par3 localization did not change in the $\mathrm{cKO}$ sciatic nerve (Fig. 5I), we wondered whether Pals1 and Par3 interact in Schwann cells. To this end, we immunoprecipitated Par3 from P21 sciatic nerve lysates. We detected Pals 1 in a protein complex with Par3 in control animals, but not cKO mice (Fig. $7 A$ ). Similarly, a $180 \mathrm{kDa}$ isoform of Par3 could be detected by immunoblot after immunoprecipitation of Pals1 (Fig. 7B). Thus, Pals 1 and Par3 interact in Schwann cells. Because Pals 1 participates in the crumbs complex, which anchors Par3 to the membrane, we asked whether the loss of Pals1 affects the amount of Par3 protein. To test this, we performed immunoblots of lysates from P21 sciatic nerve. We found the amount of Par3 protein is reduced by $\sim 40 \%$ in $\mathrm{CKO}$ mice (Fig. $7 C, D$ ). 
A
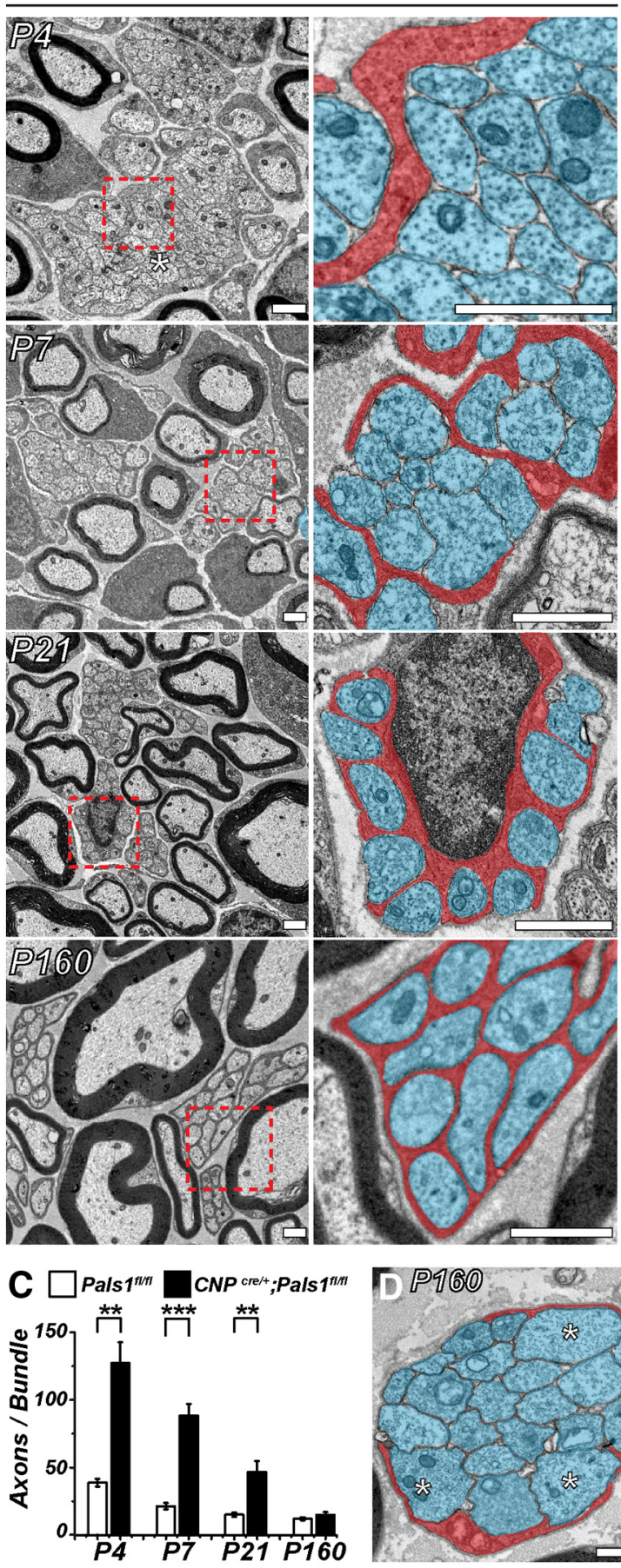

B

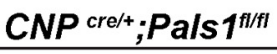


Figure 4. Radial sorting is delayed in Pals 1 cKO. $A, B$, Electron microscopy of unmyelinated axons throughout development in both control and cKO mice. Unmyelinated axons $>1 \mu \mathrm{m}$ in diameter are marked with asterisks. High-magnification images of the boxed areas with axons and Schwann cell processes pseudocolored blue and red, respectively. C, Quantification of unmyelinated axons per bundle (mean \pm SEM, one-way ANOVA followed by Bonferroni correction). ${ }^{* *} p=0.0045$ (P4); $p=0.0013$ (P21). ${ }^{* * *} p=0.0009$ (P7). $n=3$ mice (minimum 10 bundles per animal). $D$, Some nonmyelinating Schwann cells do not ensheathe each individual axon. E, Electron microscopy of cKO mice reveals polyaxonal myelination at various ages. Scale bars, $1 \mu \mathrm{m}$.

Thus, Pals1 may regulate Schwann cell polarity through interactions with the Par complex.

Pals2, a Pals1 paralog, is increased in cKO Schwann cells

The temporary delay in myelination, normal-appearing paranodes and SLIs, and the preservation of Par3 localization suggests that other, redundant mechanisms may contribute to polarity in Schwann cells and partially compensate for loss of Pals1. Consis- tent with this idea, Pals2 is expressed in Schwann cells and, like Pals1, localizes to SLIs and paranodes (Terada et al., 2012). To determine the expression level of Pals2, we performed qRT-PCR and found it modestly increased in the sciatic nerves of P21 cKO mice (Fig. 7E). Similarly, immunoblots of Pals2 protein showed increased protein levels (Fig. $7 F$ ). Thus, elevated levels of Pals2 may partially compensate for the loss of Pals1, especially at later developmental time points. 

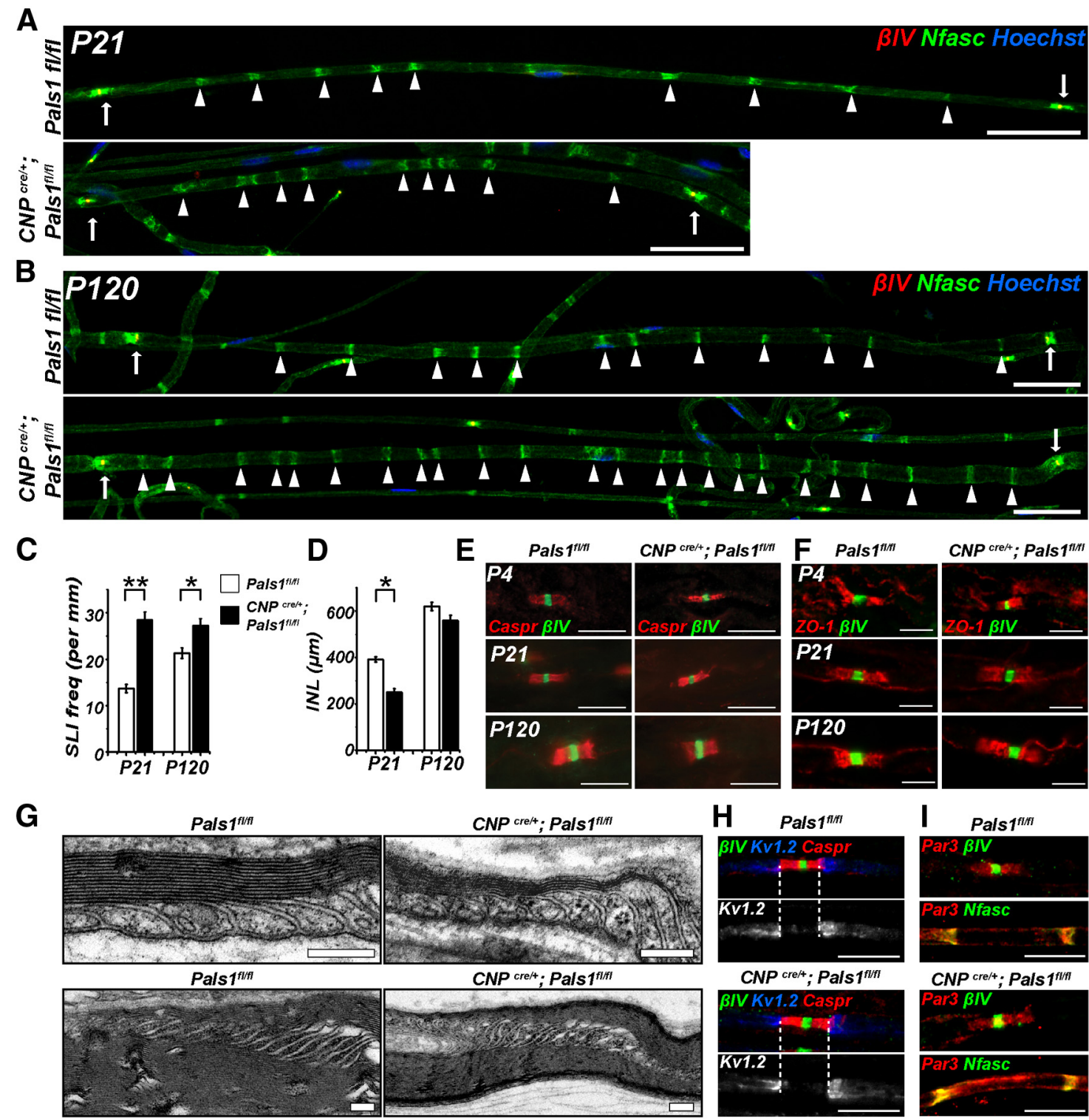

Figure 5. Loss of Pals1 increased SLI frequency, temporarily reduced internodal length, but did not affect paranodes. $A, B$, Immunostaining of teased sciatic nerves from control and cK0 mice at P21 (A) and P120 (B) stained with antibodies against pan-neurofascin (green), $\beta I V$ spectrin (red), and Hoechst (blue). Nodes and SLI are indicated by arrows and arrowheads, respectively. $\boldsymbol{C}$, The number of SLI/mm in P21 and 120 mice (mean \pm SEM, one-way ANOVA). ${ }^{* *} p=0.0008 .{ }^{*} p=0.047 . n=3$ mice (50 cells per mouse). $D$, Quantification of internodal length (INL) in P21 and P120 mice (mean \pm SEM, one-way ANOVA followed by Bonferroni correction). ${ }^{*} p=0.0025 . n=3$ mice (50 cells per mouse). E, Immunostaining of longitudinal sections of sciatic nerves from control and $c K 0$ mice. Nerves stained with antibodies against Caspr (red) and $\beta$ IV spectrin (green) at P4, P21, and P120.F, Immunostaining of teased sciatic nerves stained with antibodies against Z0-1 (red) and $\beta I V$ spectrin (green) at P4, P21, and P120. G, Electron microscopy of longitudinal sections of P21 sciatic nerve showing paranodal loops (top) and SLIs (bottom) in cK0 and control mice. $\boldsymbol{H}$, Immunostaining of teased sciatic nerves from control and cK0 mice at P21 stained with antibodies against $\beta I V$ spectrin (green), Caspr (red), and Kv1.2 (blue). Dashed lines indicate the boundary between the juxtaparanode and paranode. I, Immunostaining of teased sciatic nerves from control and cK0 mice at P21 stained with antibodies against Par3 (red) and either $\beta I V$ spectrin or pan-neurofascin (green) to label nodes and SLI, respectively. Scale bars: $\boldsymbol{A}, \boldsymbol{B}, 50 \mu \mathrm{m} ; \boldsymbol{E}, \boldsymbol{F}, \boldsymbol{H}, \boldsymbol{I}, 10 \mu \mathrm{m} ; \boldsymbol{G}, 200 \mathrm{~nm}$.

\section{Pals1 is dispensable for CNS myelination}

Given the clear role for Pals1 in the PNS, we next asked whether it is also important for CNS myelination. We performed TEM on optic nerves of cKO mice throughout development (Fig. $8 A$ ). We found that G-ratios and the percentage of myelinated axons for a given axon diameter were indistinguishable between $\mathrm{cKO}$ and control mice (Fig. $8 \mathrm{~B}, \mathrm{C}$ ). Consistent with normal myelination, cKO mouse optic nerve CAP conduction velocities were indistinguishable from control mice (Fig. 8D). Furthermore, qRT-PCR analysis of P21 spinal cord showed no significant increase in the amount of either Pals2 or Pals3 transcripts (Fig. 8E). Like the PNS, paranodes were also normal. However, in contrast to the PNS, immunostaining of optic nerve for Pals1 showed no enrich- ment at paranodes (Fig. $8 F$ ). Thus, Pals1 is dispensable for CNS myelination.

\section{Discussion}

Myelinating glia are polarized and form specialized subcellular domains with specific functions. Here, we show that Pals1dependent Schwann cell polarity regulates (1) efficient radial sorting of axons, (2) the frequency of SLIs, and (3) stability of Par3. Impaired radial sorting caused a delay in PNS myelination. However, Pals1 is not required for CNS myelination, suggesting that oligodendrocytes and Schwann cells have different mechanisms regulating their polarity. For example, whereas Schwann cells have a polarized abaxonal surface that participates in com- 
A

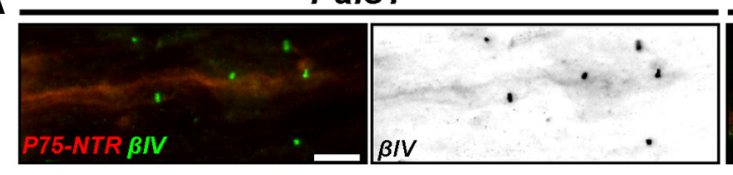

B


CNP ${ }^{\text {cre/+ }} ; P a l s 1^{\text {fl/ft }}$

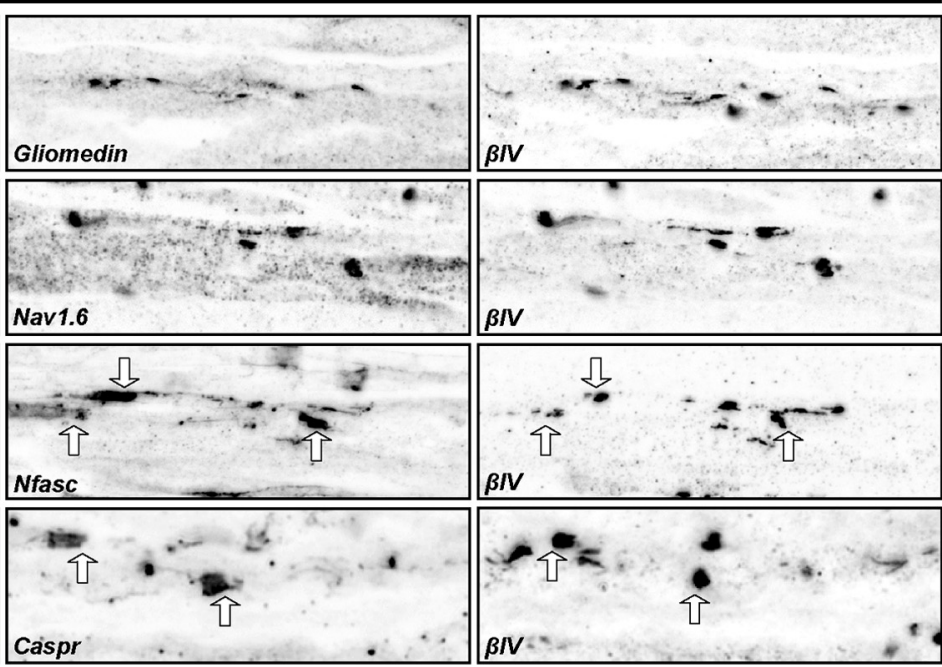

Figure 6. Ectopic node-like structures form on unmyelinated axons. $\boldsymbol{A}$, Immunostaining of longitudinal sections of sciatic nerve stained with antibodies against P75-Neurotrophin receptor (P75-NTR, red) and $\beta$ IV spectrin (green). B, Immunostaining of longitudinal sections of sciatic nerve from cK0 mice stained with antibodies against $\beta$ IV spectrin (green), gliomedin, Nav1.6, pan-neurofascin, or Caspr (red). Arrows indicate heminodes. Scale bars, $10 \mu \mathrm{m}$.

$75 \mathrm{kDa}$

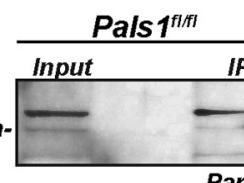

B

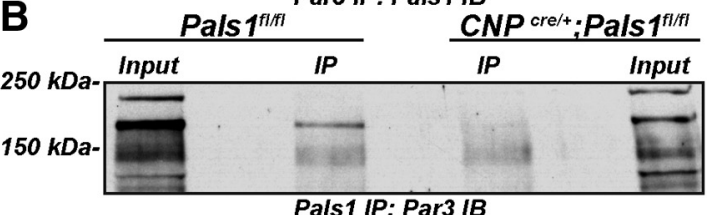

C


Pals1

$37 \mathrm{kDa}$



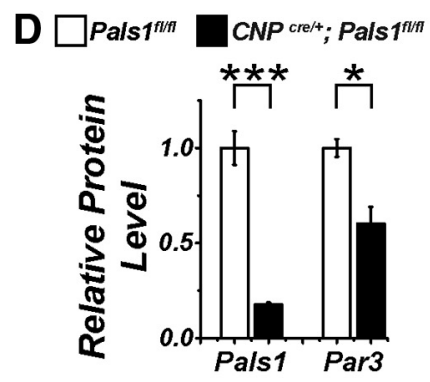

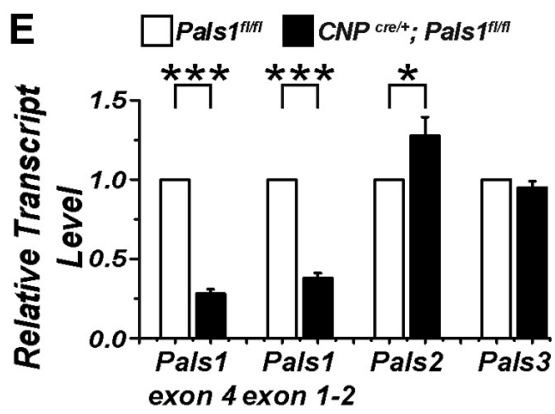

F

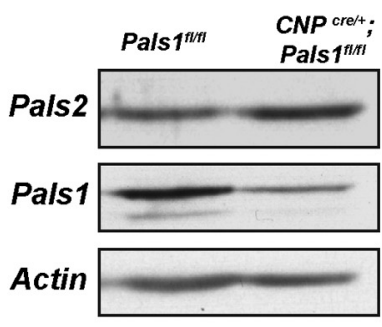

Figure 7. Pals1 interacts with Par3 in Schwann cells. $A$, Immunoblot for Pals 1 following Par3 immunoprecipitation from P21 sciatic nerves. $\boldsymbol{B}$, Immunoblot for Par 3 following Pals 1 immunoprecipitation from P21 sciatic nerves. C, Immunoblot for Par3 from P21 sciatic nerves. Actin was used as a loading control, and Pals1 is shown for comparison. D, Quantification of immunoblots from P21 sciatic nerve. Values were normalized to actin, then normalized to controls (mean \pm SEM, Student's two-tailed $t$ test, $n=3$ mice, one pair of sciatic nerves each). ${ }^{*} p=0.0165$. ${ }^{* * *} p=7.68 \times$ $10^{-4}$.E, qRT-PCR analysis of the genes encoding Pals1, Pals2, and Pals3 (mean \pm SEM, Student's two-tailed $t$ test). ${ }^{* * *} p=9.402 \times 10^{-6}$ (Pals1 exon 4); $p=0.0003$ (Pals1 exon $\left.1-2\right) .{ }^{*} p=0.03$. $n=4$ or 5 mice (one pair of sciatic nerves each). $\boldsymbol{F}$, Pals2 immunoblot of sciatic nerves pooled from 3 mice. Actin was used as a loading control, and Pals 1 is shown for comparison.

plex interactions with the basal lamina, oligodendrocytes do not. Remarkably, mice lacking laminin, or its receptors in Schwann cells (dystroglycan, $\alpha 6 \beta 1$ integrin, and $\alpha 7 \beta 1$ integrin), have defects in radial sorting and show polyaxonal myelination (Saito et al., 2003; Occhi et al., 2005; Wallquist et al., 2005; Pellegatta et al.,
2013). The similarities between the phenotypes of mice with impaired Schwann cell-basal lamina interactions and Pals1-cKO mice are striking and suggest they may participate in the same signaling pathways. Thus, we speculate that disruption of apical complex spatial regulation alters basolateral complex activity, 



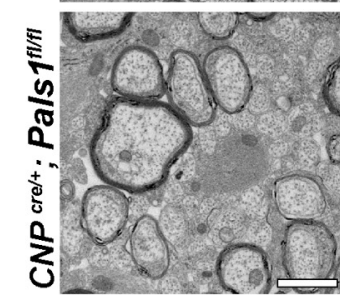

B
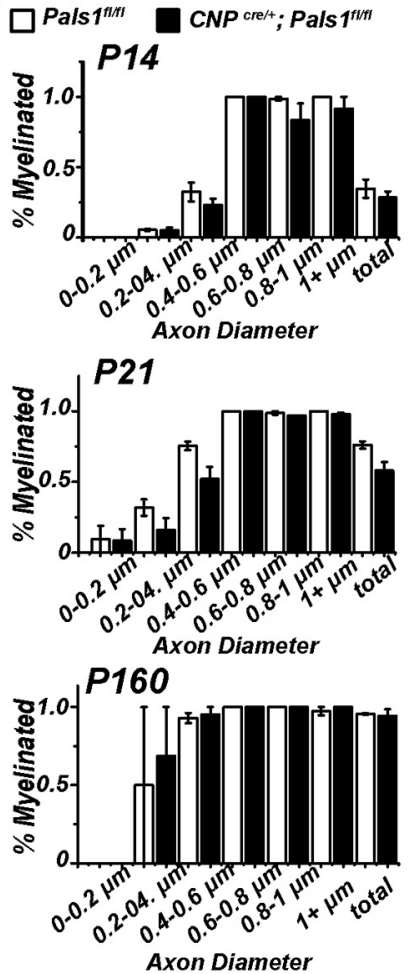

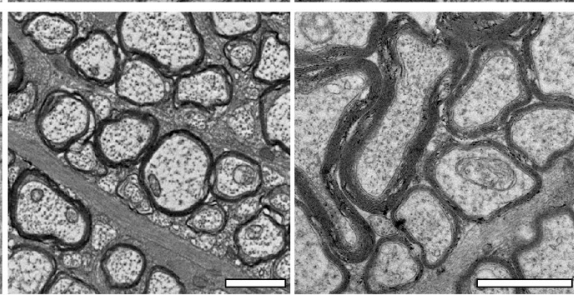

C



$P 21$
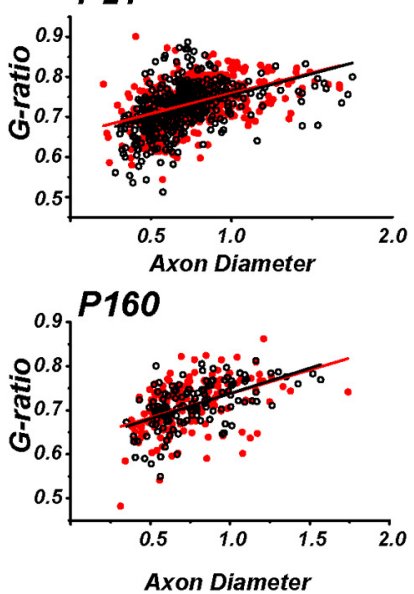

E



$\mathbf{F}$
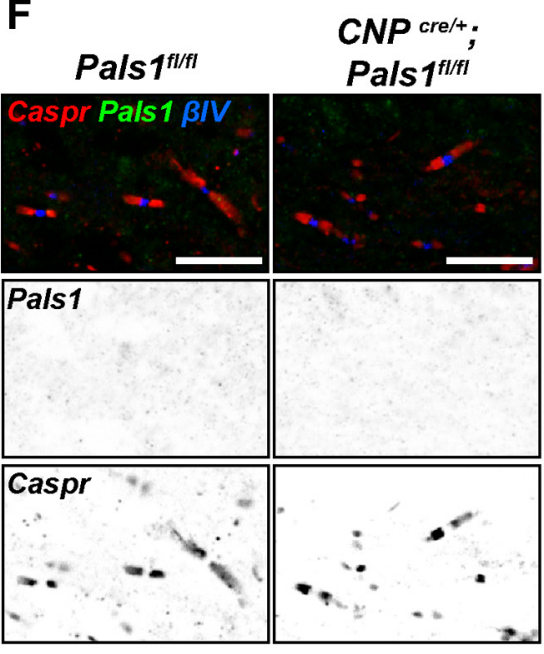

Figure 8. CNS myelination is unaffected by Pals1 CKO. $\boldsymbol{A}$, Electron microscopy of myelinated axons in the optic nerve. $\boldsymbol{B}$, Quantification of percentage myelinated axons by size (mean \pm SEM, one-way ANOVA followed by Bonferroni correction, $n=3$ mice). C, Scatter plots depicting G-ratios of control (black circles) and cKO (red dots) myelinated axons. No significant differences in average G-ratio were observed (one-way ANOVA followed by Bonferroni correction, $n=3$ mice). $D$, Conduction velocities of optic nerves throughout development (mean \pm SEM, one-way ANOVA followed by Bonferroni correction, $n \geq 8$ nerves). $\boldsymbol{E}$, qRT-PCR analysis of the genes encoding Pals1, Pals2, and Pals3 from spinal cord (mean \pm SEM, Student's two-tailed $t$ test, $n=4$ mice). ${ }^{* *} p=0.0067$ (Pals1 exon 4). ${ }^{*} p=0.025$ (Pals1 exon 1-2). $\boldsymbol{F}$, Immunostaining of P21 optic nerve with antibodies against Caspr (red), Pals1 (green), and $\beta \mathrm{IV}$ spectrin (blue). Scale bars: $\boldsymbol{A}, 1 \mu \mathrm{m} ; \boldsymbol{F}, 10 \mu \mathrm{m}$.

leading to perturbed Schwann cell-basal lamina interactions and disrupted radial sorting. Future experiments will be needed to define these connections.

Although Pals1 is enriched at paranodes and SLIs, we observed no disruption of these structures in the cKO mice. However, we did find more SLIs per internode. SLIs resemble the paranodal loops at the end of each myelinated segment and are thought to function as a pathway for trafficking of proteins across the myelin sheath and signaling between basolateral and apical compartments of the Schwann cell (Peters et al., 1976). Like Pals1, other polarity proteins, including Par3, are also found in SLIs (Poliak et al., 2002). However, the mechanisms controlling the number and location of SLIs along an internode remain poorly characterized. Our observations suggest that Pals1 may directly regulate the number of SLIs per internode. Alternatively, the increased frequency of SLIs may simply be a secondary consequence of the transient delay in myelination. Determining the frequency of SLIs in mouse models with delayed myelination unrelated to loss of polarity proteins (e.g., Lgi4 mutant mice) (Bermingham et al., 2006) may help distinguish among these possibilities. Dysregulation of basolateral elements in Pals $1 \mathrm{cKO}$ mice may also regulate SLI frequency. For example, DLG1 interacts with PTEN (phosphatase and tensin homolog deleted on chromosome 10) to act as a "brake" on myelination (Cotter et al., 2010). PTEN ablation leads to the formation of myelin outfoldings from SLIs and paranodes (Goebbels et al., 2012). Thus, de- 
stabilization of the apical complex may promote a local increase in DLG1, leading to a local halt in myelin production and increased SLI formation.

Despite the lack of paranode disruption in Pals1 cKO mice, we frequently observed aberrant clusters of nodal proteins. These sometimes included heminodes (nodal protein clusters flanked on one side by paranodal junctions), but most often consisted of irregularly shaped aggregates of $\beta \mathrm{IV}$ spectrin, gliomedin, ankG, $\mathrm{Nfasc}$, and $\mathrm{Na}^{+}$channels. We speculate that the heminodes arise from discontinuously myelinated axons: axons that in some regions are correctly sorted and myelinated, but in other regions are incorrectly sorted and associated with a nonmyelinating Schwann cell. In contrast, the mechanisms responsible for the abnormal clusters not associated with a flanking paranodal junction are more enigmatic. Because the clusters contain gliomedin, they may reflect excess gliomedin in these incorrectly sorted bundles of axons, or secreted gliomedin may have access to naked axons not properly ensheathed by nonmyelinating Schwann cells (e.g., Fig. 4D). Remarkably, laminin-deficient mice show discontinuously myelinated axons (Stirling, 1975) and virtually identical clusters of node-associated proteins without any overlying myelin (Deerinck et al., 1997). We speculate that mutant mice lacking Schwann cell laminin receptors may also have similar clusters.

Using lentiviral delivery of shRNA to silence expression of Pals1 in postnatal, myelinating Schwann cells, Ozçelik et al. (2010) previously reported severe thinning of the myelin sheath and a drastic reduction in internodal length. In contrast, we report that PNS myelin thickness was unaffected and the reduction in internodal length was temporary in Pals1 cKO mice. What accounts for these differences? Viral transduction of Schwann cells and the use of shRNA may reduce the temporal precision and efficiency of Pals1 deletion. The difference in measured myelin thickness may reflect limitations in experimental methods: Ozçelik et al. (2010) used confocal imaging, whereas we used much more sensitive TEM. Alternatively, while the cKO guarantees loss of Pals1 at precisely defined developmental stages, we found that the amount of Pals2 increased after Pals1 deletion. Pals1 expression decreases with increasing age, suggesting reduced dependence on Pals1 with increasing Schwann cell maturity. Thus, the different Schwann cell phenotypes may reflect compensatory changes that occur specifically in the Pals $1 \mathrm{cKO}$ and not in Schwann cells with viral knockdown of Pals1.

In many polarized cell types, Pals 1 is central to establish polarized domains. Why does loss of Pals1 not have a more significant effect on myelination or paranode formation? As in several other mutants with loss of polarity proteins in myelinating glia (Beirowski et al., 2014; Pooya et al., 2014; Shen et al., 2014; Jarjour et al., 2015) (e.g., Par4 and Scribble), we observed a delay in myelination rather than frank arrest or disruption of myelin and its associated domain; the delay likely reflects impaired radial sorting. These observations suggest that, in myelinating glia, compensation or redundancy may frequently occur among some polarity complexes. This is consistent with the increase in Pals2 protein expression levels after Pals1 deletion. Thus, double knock-outs lacking both Pals1 and Pals2 may be necessary to determine their involvement in myelination. Alternatively, inducible conditional knock-outs may reveal the role of polarity in mature Schwann cells and bypass developmental compensation. Finally, because polarity proteins function in large complexes, removing multiple polarity proteins may be required before Schwann cell polarity is completely disrupted. For example, we showed that Pals1 interacts with Par3 in the sciatic nerve, suggest- ing that Schwann cells use evolutionary conserved mechanisms of polarity. However, reduction in the amount of Par3 protein after Pals1 deletion did not disrupt myelination.

Oligodendrocytes express canonical polarity proteins, some of which have even been implicated in oligodendrocyte development (Binamé et al., 2013). Recently, RNA sequencing indicated that Pals1 expression peaks in newly formed oligodendrocytes and then decreases in myelinating oligodendrocytes (Zhang et al., 2014). Despite its expression in oligodendrocytes, Pals1 is not found at paranodes and does not appear to regulate myelination. That some polarity proteins may play important roles in the PNS, but not CNS, is further underscored by the observation that mice lacking the polarity protein, Par4, have a profound delay in PNS myelination, but no defect in CNS myelination (Shen et al., 2014). In contrast, the polarity protein Scribble regulates CNS myelin initiation, longitudinal extension, thickness, and paranode formation (Jarjour et al., 2015).

In conclusion, we show here that the polarity protein Pals1 plays important roles in regulating Schwann cell functions during early development. However, because Pals1 is dispensable for CNS myelination, oligodendrocytes and Schwann cells must have distinct requirements for polarity. We propose that future studies to determine the unique polarity complexes in Schwann cells and oligodendrocytes may yield important insights into how these cells develop their complex morphologies and specialized signaling domains, including myelin and paranodal junctions.

\section{References}

Assémat E, Bazellières E, Pallesi-Pocachard E, Le Bivic A, Massey-Harroche D (2008) Polarity complex proteins. Biochim Biophys Acta 1778:614-630. CrossRef Medline

Beirowski B, Babetto E, Golden JP, Chen YJ, Yang K, Gross RW, Patti GJ, Milbrandt J (2014) Metabolic regulator LKB1 is crucial for Schwann cell-mediated axon maintenance. Nat Neurosci 17:1351-1361. CrossRef Medline

Bermingham JR Jr, Shearin H, Pennington J, O’Moore J, Jaegle M, Driegen S, van Zon A, Darbas A, Ozkaynak E, Ryu EJ, Milbrandt J, Meijer D (2006) The claw paw mutation reveals a role for Lgi4 in peripheral nerve development. Nat Neurosci 9:76-84. CrossRef Medline

Bhat MA, Rios JC, Lu Y, Garcia-Fresco GP, Ching W, St Martin M, Li J, Einheber S, Chesler M, Rosenbluth J, Salzer JL, Bellen HJ (2001) Axonglia interactions and the domain organization of myelinated axons requires neurexin IV/Caspr/Paranodin. Neuron 30:369-383. CrossRef Medline

Binamé F, Sakry D, Dimou L, Jolivel V, Trotter J (2013) NG2 regulates directional migration of oligodendrocyte precursor cells via Rho GTPases and polarity complex proteins. J Neurosci 33:10858-10874. CrossRef Medline

Chan JR, Jolicoeur C, Yamauchi J, Elliott J, Fawcett JP, Ng BK, Cayouette M (2006) The polarity protein Par-3 directly interacts with p75NTR to regulate myelination. Science 314:832-836. CrossRef Medline

Chang KJ, Susuki K, Dours-Zimmermann MT, Zimmermann DR, Rasband MN (2010) Oligodendrocyte myelin glycoprotein does not influence node of ranvier structure or assembly. J Neurosci 30:14476-14481. CrossRef Medline

Chang KJ, Zollinger DR, Susuki K, Sherman DL, Makara MA, Brophy PJ, Cooper EC, Bennett V, Mohler PJ, Rasband MN (2014) Glial ankyrins facilitate paranodal axoglial junction assembly. Nat Neurosci 17:16731681. CrossRef Medline

Cosgaya JM, Chan JR, Shooter EM (2002) The neurotrophin receptor p75NTR as a positive modulator of myelination. Science 298:1245-1248. CrossRef Medline

Cotter L, Ozçelik M, Jacob C, Pereira JA, Locher V, Baumann R, Relvas JB, Suter U, Tricaud N (2010) Dlg1-PTEN interaction regulates myelin thickness to prevent damaging peripheral nerve overmyelination. Science 328:1415-1418. CrossRef Medline

Deerinck TJ, Levinson SR, Bennett GV, Ellisman MH (1997) Clustering of voltage-sensitive sodium channels on axons is independent of direct 
Schwann cell contact in the dystrophic mouse. J Neurosci 17:5080-5088. Medline

Eshed Y, Feinberg K, Poliak S, Sabanay H, Sarig-Nadir O, Spiegel I, Bermingham JR Jr, Peles E (2005) Gliomedin mediates Schwann cell-axon interaction and the molecular assembly of the nodes of Ranvier. Neuron 47: 215-229. CrossRef Medline

Feltri ML, Poitelon Y, Previtali SC (2015) How Schwann cells sort axons: new concepts. Neuroscientist. Advance online publication. Retrieved Feb. 16, 2015. doi: 10.1177/1073858415572361. CrossRef Medline

Goebbels S, Oltrogge JH, Wolfer S, Wieser GL, Nientiedt T, Pieper A, Ruhwedel T, Groszer M, Sereda MW, Nave KA (2012) Genetic disruption of Pten in a novel mouse model of tomaculous neuropathy. EMBO Mol Med 4:486-499. CrossRef Medline

Jarjour AA, Boyd A, Dow LE, Holloway RK, Goebbels S, Humbert PO, Williams A, ffrench-Constant C (2015) The polarity protein scribble regulates myelination and remyelination in the central nervous system. PLoS Biol 13:e1002107. CrossRef Medline

Kim S, Lehtinen MK, Sessa A, Zappaterra MW, Cho SH, Gonzalez D, Boggan B, Austin CA, Wijnholds J, Gambello MJ, Malicki J, LaMantia AS, Broccoli V, Walsh CA (2010) The apical complex couples cell fate and cell survival to cerebral cortical development. Neuron 66:69-84. CrossRef Medline

Lappe-Siefke C, Goebbels S, Gravel M, Nicksch E, Lee J, Braun PE, Griffiths IR, Nave KA (2003) Disruption of Cnp1 uncouples oligodendroglial functions in axonal support and myelination. Nat Genet 33:366-374. CrossRef Medline

Masaki T (2012) Polarization and myelination in myelinating glia. ISRN Neurol 2012:769412. CrossRef Medline

McCaffrey LM, Macara IG (2009) Widely conserved signaling pathways in the establishment of cell polarity. Cold Spring Harb Perspect Biol 1:a001370. CrossRef Medline

Mellman I, Nelson WJ (2008) Coordinated protein sorting, targeting and distribution in polarized cells. Nat Rev Mol Cell Biol 9:833-845. CrossRef Medline

Michailov GV, Sereda MW, Brinkmann BG, Fischer TM, Haug B, Birchmeier C, Role L, Lai C, Schwab MH, Nave KA (2004) Axonal neuregulin-1 regulates myelin sheath thickness. Science 304:700-703. CrossRef Medline

Occhi S, Zambroni D, Del Carro U, Amadio S, Sirkowski EE, Scherer SS, Campbell KP, Moore SA, Chen ZL, Strickland S, Di Muzio A, Uncini A, Wrabetz L, Feltri ML (2005) Both laminin and Schwann cell dystroglycan are necessary for proper clustering of sodium channels at nodes of Ranvier. J Neurosci 25:9418-9427. CrossRef Medline

Ogawa Y, Schafer DP, Horresh I, Bar V, Hales K, Yang Y, Susuki K, Peles E, Stankewich MC, Rasband MN (2006) Spectrins and ankyrinB constitute a specialized paranodal cytoskeleton. J Neurosci 26:5230-5239. CrossRef Medline

Ozçelik M, Cotter L, Jacob C, Pereira JA, Relvas JB, Suter U, Tricaud N (2010) Pals1 is a major regulator of the epithelial-like polarization and the extension of the myelin sheath in peripheral nerves. J Neurosci 30: 4120-4131. CrossRef Medline

Park B, Alves CH, Lundvig DM, Tanimoto N, Beck SC, Huber G, Richard F, Klooster J, Andlauer TF, Swindell EC, Jamrich M, Le Bivic A, Seeliger MW, Wijnholds J (2011) PALS1 is essential for retinal pigment epithelium structure and neural retina stratification. J Neurosci 31:1723017241. CrossRef Medline

Pellegatta M, De Arcangelis A, D'Urso A, Nodari A, Zambroni D, Ghidinelli M, Matafora V, Williamson C, Georges-Labouesse E, Kreidberg J, Mayer U, McKee KK, Yurchenco PD, Quattrini A, Wrabetz L, Feltri ML (2013) alpha6betal and alpha7betal integrins are required in Schwann cells to sort axons. J Neurosci 33:17995-18007. CrossRef Medline

Peters A, Palay SL, Webster HD (1976) The fine structure of the nervous system: the neurons and supporting cells. Philadelphia: Saunders.

Poliak S, Matlis S, Ullmer C, Scherer SS, Peles E (2002) Distinct claudins and associated PDZ proteins form different autotypic tight junctions in myelinating Schwann cells. J Cell Biol 159:361-372. CrossRef Medline

Pooya S, Liu X, Kumar VB, Anderson J, Imai F, Zhang W, Ciraolo G, Ratner
N, Setchell KD, Yoshida Y,Yutaka Y, Jankowski MP, Dasgupta B (2014) The tumour suppressor LKB1 regulates myelination through mitochondrial metabolism. Nat Commun 5:4993. CrossRef Medline

Radonić A, Thulke S, Mackay IM, Landt O, Siegert W, Nitsche A (2004) Guideline to reference gene selection for quantitative real-time PCR. Biochem Biophys Res Commun 313:856-862. CrossRef Medline

Saito F, Moore SA, Barresi R, Henry MD, Messing A, Ross-Barta SE, Cohn RD, Williamson RA, Sluka KA, Sherman DL, Brophy PJ, Schmelzer JD, Low PA, Wrabetz L, Feltri ML, Campbell KP (2003) Unique role of dystroglycan in peripheral nerve myelination, nodal structure, and sodium channel stabilization. Neuron 38:747-758. CrossRef Medline

Salzer JL (2003) Polarized domains of myelinated axons. Neuron 40:297318. CrossRef Medline

Salzer JL (2012) Axonal regulation of Schwann cell ensheathment and myelination. J Peripher Nerv Syst 17 [Suppl 3]:14-19.

Schafer DP, Bansal R, Hedstrom KL, Pfeiffer SE, Rasband MN (2004) Does paranode formation and maintenance require partitioning of neurofascin 155 into lipid rafts? J Neurosci 24:3176-3185. CrossRef Medline

Schafer DP, Custer AW, Shrager P, Rasband MN (2006) Early events in node of Ranvier formation during myelination and remyelination in the PNS. Neuron Glia Biol 2:69-79. CrossRef Medline

Shen YA, Chen Y, Dao DQ, Mayoral SR, Wu L, Meijer D, Ullian EM, Chan JR, Lu QR (2014) Phosphorylation of LKB1/Par-4 establishes Schwann cell polarity to initiate and control myelin extent. Nat Commun 5:4991. CrossRef Medline

Simons M, Snaidero N, Aggarwal S (2012) Cell polarity in myelinating glia: from membrane flow to diffusion barriers. Biochim Biophys Acta 1821: 1146-1153. CrossRef Medline

Stirling CA (1975) Abnormalities in Schwann cell sheaths in spinal nerve roots of dystrophic mice. J Anat 119:169-180. Medline

Straight SW, Shin K, Fogg VC, Fan S, Liu CJ, Roh M, Margolis B (2004) Loss of PALS1 expression leads to tight junction and polarity defects. Mol Biol Cell 15:1981-1990. CrossRef Medline

Susuki K, Raphael AR, Ogawa Y, Stankewich MC, Peles E, Talbot WS, Rasband MN (2011) Schwann cell spectrins modulate peripheral nerve myelination. Proc Natl Acad Sci U S A 108:8009-8014. CrossRef Medline

Taveggia C, Zanazzi G, Petrylak A, Yano H, Rosenbluth J, Einheber S, Xu X, Esper RM, Loeb JA, Shrager P, Chao MV, Falls DL, Role L, Salzer JL (2005) Neuregulin-1 type III determines the ensheathment fate of axons. Neuron 47:681-694. CrossRef Medline

Tep C, Kim ML, Opincariu LI, Limpert AS, Chan JR, Appel B, Carter BD, Yoon SO (2012) Brain-derived neurotrophic factor (BDNF) induces polarized signaling of small GTPase (Racl) protein at the onset of Schwann cell myelination through partitioning-defective 3 (Par3) protein. J Biol Chem 287:1600-1608. CrossRef Medline

Terada N, Saitoh Y, Ohno N, Komada M, Saitoh S, Peles E, Ohno S (2012) Essential function of protein $4.1 \mathrm{G}$ in targeting of membrane protein palmitoylated 6 into Schmidt-Lanterman incisures in myelinated nerves. Mol Cell Biol 32:199-205. CrossRef Medline

Wallquist W, Plantman S, Thams S, Thyboll J, Kortesmaa J, Lännergren J, Domogatskaya A, Ogren SO, Risling M, Hammarberg H, Tryggvason K, Cullheim S (2005) Impeded interaction between Schwann cells and axons in the absence of laminin alpha4. J Neurosci 25:3692-3700. CrossRef Medline

Yang Y, Lacas-Gervais S, Morest DK, Solimena M, Rasband MN (2004) BetaIV spectrins are essential for membrane stability and the molecular organization of nodes of Ranvier. J Neurosci 24:7230-7240. CrossRef Medline

Zhang C, Susuki K, Zollinger DR, Dupree JL, Rasband MN (2013) Membrane domain organization of myelinated axons requires betaII spectrin. J Cell Biol 203:437-443. CrossRef Medline

Zhang Y, Chen K, Sloan SA, Bennett ML, Scholze AR, O'Keeffe S, Phatnani HP, Guarnieri P, Caneda C, Ruderisch N, Deng S, Liddelow SA, Zhang C, Daneman R, Maniatis T, Barres BA, Wu JQ (2014) An RNA-sequencing transcriptome and splicing database of glia, neurons, and vascular cells of the cerebral cortex. J Neurosci 34:11929-11947. CrossRef Medline 